\title{
GRAVITY DATA COLLECTED ALONG THE LOS ANGELES REGIONAL SEISMIC EXPERIMENT (LARSE) AND PRELIMINARY MODEL OF REGIONAL DENSITY VARIATIONS IN BASEMENT ROCKS, SOUTHERN CALIFORNIA
}

\author{
By \\ V.E. Langenheim ${ }^{1}$ and R.C. Jachens ${ }^{1}$
}

1996

Open-File Report 96-682

This report is preliminary and has not been reviewed for conformity with U.S. Geological Survey editorial standards or with the North American Stratigraphic Code. Any use of trade, firm, or product names is for descriptive purposes only and does not imply endorsement by the U.S. Government.

${ }^{1}$ U.S. Geological Survey, MS 989, 345 Middlefield Road, Menlo Park, CA 94025 


\section{TABLE OF CONTENTS}

Abstract
Introduction
Acknowledgments
Geologic Setting .
Gravity Data
Gravity Anomalies along the LARSE profile
Depth to Basement
Method
Results
References .

Table

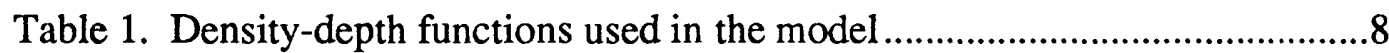

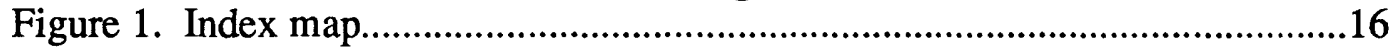

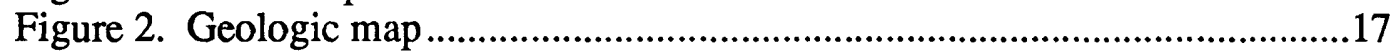

Figure 3. Map of gravity station coverage ..........................................................18

Figure 4a. Complete Bouguer gravity values along LARSE .................................19

Figure 4b. Isostatic gravity values along LARSE .................................................20

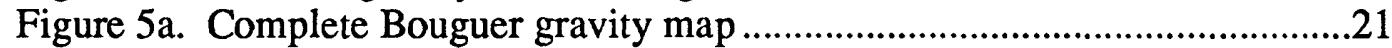

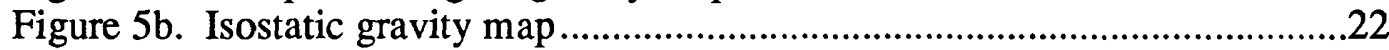

Figure 6. Schematic representation of gravity separation procedure .....................23

Figure 7. Thickness of Cenozoic deposits..........................................................24

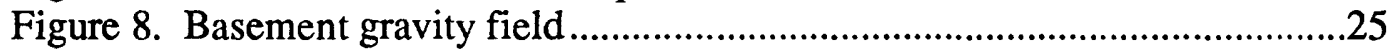




\begin{abstract}
The U.S. Geological Survey conducted a detailed gravity study along part of the Los Angeles Regional Seismic Experiment (LARSE) transect across the Los Angeles Basin and San Gabriel Mountains to help characterize the structure underlying this area. More than 400 gravity measurements were collected along the transect and along the Los Angeles basin-San Gabriel Mountains interface. The observed isostatic gravity field was separated into two components: a "basin" component caused by the accumulation of basin fill and a "basement" component reflecting density variations in the basement rocks. A gravity low of more than $65 \mathrm{mGal}$ reflects the deep Los Angeles basin where inversion of the basin gravity field indicates thicknesses of Cenozoic sedimentary and volcanic rocks of more than $10 \mathrm{~km}$. The modeled basement gravity field indicates that the LARSE transect crosses the northern extension of a pronounced basement gravity and aeromagnetic high over the San Joaquin Hills, reflecting basement rocks of the western Peninsular Ranges or, alternatively, Miocene basic intrusive rocks. The basement gravity field indicates that a major decrease in the density of basement rocks from the San Gabriel Mountains to the Mojave Desert occurs approximately at the San Andreas fault.
\end{abstract}

\title{
Introduction
}

The U.S. Geological Survey conducted a detailed gravity study along part of the Los Angeles Regional Seismic Experiment (LARSE) transect across the Los Angeles Basin and San Gabriel Mountains to help characterize the structure underlying this area (Fig. 1). The goal of the LARSE transect is to image the major, active geologic structures of the Los Angeles region including the San Andreas fault, the frontal thrust fault system of the Transverse Ranges, and blind thrust faults and folds in the Los Angeles basin. Gravity data were also collected along the basin-mountain interface and the Northridge epicentral area. More than 400 gravity measurements were collected during two field sessions. In order to constrain the densities of the basement rocks, we used a modified version of Jachens and Moring's (1990) method to separate the observed gravity field into components caused by variations in basin thickness (the basin gravity field) and density variations of the basement rocks (basement gravity field). The variations in the basement gravity field can then be compared to variations of seismic velocities measured along the LARSE transect.

\section{Acknowledgments}

Robert L. Morin and Robert F. Sikora of the U.S. Geological Survey assisted in the field and in the office, respectively. We also thank Janice Murphy and Gary Fuis of the 
U.S. Geological Survey for providing logistical support for the field work. Larry Beyer and Tom Hildenbrand of the U.S. Geological Survey provided thoughtful and helpful reviews of the manuscript.

\section{Geologic Setting}

The LARSE transect crosses several geologic provinces, from the Los Angeles basin across the San Gabriel Mountains to the Mojave Desert (Fig. 1). This region has experienced a complex Tertiary history including subduction, strike-slip faulting, extension, and large-scale rotation (Crouch and Suppe, 1993).

The Los Angeles basin is a large alluviated depression that is located at the juncture of three primary physiographic provinces of coastal southern California: the Peninsular Ranges, the Transverse Ranges, and the Continental Borderland. The present shape of the basin began to form in late Miocene, subsiding in response to movement on the rightoblique Whittier and Palos Verdes faults and left-oblique Santa Monica fault system (Wright, 1990). Calc-alkaline volcanism accompanied the maximum extensional phase during the middle Miocene. During the Pliocene, extension ended and contraction began. This transition occurred rapidly and coincided temporally with a change in relative plate motion at about 3.4 to $3.9 \mathrm{Ma}$ (Wright, 1990).

The San Gabriel Mountains are part of the east-trending Transverse Ranges and lie oblique to the predominant northwest structural grain of California. Their high relief developed in response to north-south compression during the past 2 to 3 million years (Crowell, 1976). Paleomagnetic studies indicate that the rocks of the Transverse Ranges rotated clockwise, beginning in the middle Miocene (Luyendyk and Hornafius, 1987). The San Gabriel Mountains consist of Precambrian and Paleozoic metamorphic and plutonic rocks and Mesozoic granitic rocks (Bortugno and Spittler, 1986). They are bounded by the San Gabriel fault and the Sierra Madre fault zone on the south and by the San Andreas fault on the north. The San Gabriel fault is a right-lateral strike-slip fault with as much as $60 \mathrm{~km}$ of offset (Bohannon, 1975); the Sierra Madre fault zone is a thrust fault system that dips to the north beneath the mountains (Crook and others, 1987). Sheffels and McNutt (1986) suggested that the lack of correlation of Bouguer gravity with topography indicates the absence of a classic "Airy root" beneath the mountain range and that the topography of the range is supported by a rigid lithosphere.

The Mojave block is a relatively featureless, high-standing (approximately $700 \mathrm{~m}$ above sea level) alluvial plain that is separated into valleys or closed basins by hills and low mountains. The region is underlain by a pre-Tertiary basement complex consisting largely of Mesozoic plutonic rocks and pendants of metasedimentary and metavolcanic 
rocks. The plutonic rocks underlie much of the area of the LARSE transect. Their composition ranges from nearly ultramafic to highly silicic, but most exposed plutonic rocks are quartz monzonite or granite in composition (Dibblee, 1981). The basement complex is overlain unconformably by Tertiary sedimentary and volcanic rocks. Several northwest-trending strike-slip faults cut across the Mojave Desert.

To perform the depth to basement modeling and to isolate the gravity field produced by variations in density of the basement rocks, the geology of the area was divided into two basic units. Basement rocks are defined to be all pre-Cenozoic rocks and Cenozoic igneous intrusive rocks. Basin rocks are defined to be Cenozoic and are further divided into sedimentary and extrusive volcanic units (Fig. 2).

\section{Gravity Data}

More than 400 gravity measurements were collected with LaCoste \& Romberg gravity meter G-614 during April 1994 and June 1995 to supplement regional gravity coverage (more than 18,000 stations; Fig. 3; Oliver and others, 1981) and provide detailed data over the seismic transect (Figs. 4a,b). Along the transect 266 stations were collected. Additional gravity stations were collected on basement exposures to augment the regional coverage. The new data in the Los Angeles basin and San Gabriel Mountains south of San Andreas fault were tied to base station, PBB6 (observed gravity $979389.013 \mathrm{mGal}$; Roberts and Jachens, 1986). Data collected in the Mojave Desert and San Gabriel Mountains north of the San Andreas fault were tied to base station PB0712 (observed gravity 979413.037; Roberts and Jachens, 1986). Data collected in the San Fernando Valley area were tied to base station PBB1 (observed gravity $979545.081 \mathrm{mGal}$; Roberts and Jachens, 1986).

Gravity data were reduced using the Geodetic Reference System of 1967 (International Union of Geodesy and Geophysics, 1971) and referenced to the International Gravity Standardization Net 1971 gravity datum (Morelli, 1974, p. 18). Gravity data were reduced to complete Bouguer and isostatic residual anomalies using a reduction density of $2670 \mathrm{~kg} / \mathrm{m}^{3}$. These data have been corrected for earth-tide, instrument drift, free-air, Bouguer, latitude, curvature, and terrain. An isostatic correction using a sea-level crustal thickness of $25 \mathrm{~km}$, a crustal density of $2670 \mathrm{~kg} / \mathrm{m}^{3}$, and a mantle-crust density contrast of $400 \mathrm{~kg} / \mathrm{m}^{3}$ was applied to the gravity data to remove long-wavelength crustal gravity effects due to topographic loading (Jachens and Griscom, 1985).

Horizontal control on the gravity station locations was provided by U.S. Geological Survey 7-1/2 minute topographic series maps and Global Positioning System 
observations. Altimetry, using benchmark and spot elevation control from U.S. Geological Survey 7-1/2 minute series maps, provided a majority of the station elevations in the mountain areas along the LARSE transect. The uncertainty in the elevations of the stations is probably $3 \mathrm{~m}$ or less, with a corresponding uncertainty in the reduced gravity values of less than $0.6 \mathrm{mGal}$.

Terrain corrections were computed to a radial distance of $167 \mathrm{~km}$ and involved a 3part process: (1) Hayford-Bowie zones A and B with an outer radius of $68 \mathrm{~m}$ were estimated in the field with the aid of tables and charts, (2) Hayford-Bowie zones C and D with an outer radius of $590 \mathrm{~m}$ were computed by hand, and (3) terrain corrections from a distance of $0.59 \mathrm{~km}$ to $167 \mathrm{~km}$ were calculated using a digital elevation model and a procedure by Plouff (1977). Total terrain corrections for the stations collected for this study ranged from 0.1 to $32.0 \mathrm{mGal}$, averaging $5.8 \mathrm{mGal}$. Uncertainties resulting from the terrain correction range from less than $0.1 \mathrm{mGal}$ in the relatively flat areas of the Los Angeles basin and Mojave Desert to as much as $3.2 \mathrm{mGal}$ in the most mountainous part of the San Gabriel Mountains.

\section{Gravity Anomalies Along the LARSE Profile}

Although profiles of both complete Bouguer and isostatic gravity anomalies (Figs. $4 a, b$ and Figs. 5a,b) are presented, discussion will be hereafter limited to the isostatic gravity datasets in this report. Isostatic gravity anomalies presumably reflect the density distribution within the upper and middle crust and provide a convenient starting point for separating the gravity field into basement and basin components. The isostatic gravity field is, however, a modeled result and therefore is not perfect; for this reason, we have also included the complete Bouguer gravity map and profile.

The dominant features in the southern California isostatic gravity field are the gravity lows over the Los Angeles, Ventura, and San Fernando basins and the gravity highs over the Palos Verdes Hills, western Transverse Ranges and Peninsular Ranges (Fig. 5b). The regional gravity data show that the Los Angeles basin is characterized by isostatic gravity values as low as $-65 \mathrm{mGal}$. The LARSE transect crosses southeast of the deepest part of the basin where Miocene and younger sedimentary rocks are more than $10 \mathrm{~km}$ thick (McCulloh, 1960; see below). The detailed gravity profile begins at the coastline about 2 $\mathrm{km}$ south of the Newport-Inglewood fault zone on the southwestern flank of the basin. Although the profile data only image the onshore part of the gradient associated with the southwestern margin of the Los Angeles basin, offshore data indicate that isostatic values continue to rise to a maximum value of $-3 \mathrm{mGal}$ about $10 \mathrm{~km}$ offshore (Fig. $5 \mathrm{~b}$ ). This 
offshore gravity high appears to mark the southwestern continuation of the gravity high over the Palos Verdes Hills, a basement ridge where Catalina Schist is exposed.

The gravity gradient associated with the northeastern margin of the Los Angeles basin is not as smooth or as linear as the gradient associated with the southwest edge of the basin. The base of the gradient is marked by an abrupt step of $2-3 \mathrm{mGal}$ at about $\mathrm{km} 15$; the Norwalk fault, according to Jennings (1962), would intersect the profile at about $\mathrm{km}$ 18. An inflection on the gradient at about $\mathrm{km} 26$ (Fig. 4b) coincides with the extension of the Anaheim nose, a completely buried ridge of Paleogene rocks that plunges to the northwest (Wright, 1990). The Anaheim nose partly coincides with a ridge of higher gravity values that appear to be the northwestern extension of the northern edge of a large gravity high (values of $+10 \mathrm{mGal}$; Fig. $5 \mathrm{~b}$ ) that occurs over Miocene sedimentary and volcanic rocks exposed in the San Joaquin Hills.

Along the profile, the gravity values decrease to their lowest value $(-56 \mathrm{mGal})$ at $\mathrm{km}$ 13. The gravity field then increases northeastward to values of $-27 \mathrm{mGal}$ just north of the Whittier fault. A local gravity high of about 8-10 mGal centered just north of the Whittier fault zone interrupts the gravity gradient between the Los Angeles basin and the San Gabriel Mountains. This north-northwest-trending gravity high is bounded by the Whittier and Whittier Heights faults and probably reflects an uplifted basement wedge (Yerkes, 1972). Significant thinning of mid-Mohnian sandstones across this uplift suggests that it is a relict of mid-Miocene block faulting (Wright, 1990). Although the Whittier fault apparently terminates against the nearly north-trending East Montebello fault in the vicinity of Whittier Narrows (about $3 \mathrm{~km}$ west of where the LARSE transect crosses the Whittier fault; Wright, 1990), the strong gravity gradient associated with the Whittier fault continues westward for at least $10 \mathrm{~km}$. Here the gravity gradient may reflect the Alhambra high, an area of shallow basement rocks (buried less than $1 \mathrm{~km}$ ) that is undergoing active uplift today (Wright, 1990).

North of the Whittier fault, the regional gravity field is relatively flat, with values ranging from about -30 to $-20 \mathrm{mGal}$ (Fig. 4,5 ). The rather featureless gravity field over the San Gabriel Valley is interrupted by a north-northeast-trending gravity high over the San Jose Hills, but this local high does not intersect the transect (Fig. 4b, 5b). Along the profile gravity values gradually increase to about $-20 \mathrm{mGal}$ at the foot of the San Gabriel Mountains. A local gravity low of $3 \mathrm{mGal}$ occurs at the base of San Gabriel Canyon between the Duarte and Sierra Madre faults (Fig. 4b). These frontal thrust faults mark the beginning of an abrupt increase in gravity values to nearly $0 \mathrm{mGal}$ over the crystalline basement rocks of the San Gabriel Mountains. 
North of the Duarte fault gravity values range from 0 to $-8 \mathrm{mGal}$ over the crystalline basement rocks of the San Gabriel Mountains. These values along the profile are consistent with those of the regional data set. Throughout the San Gabriel Mountains, values over $0 \mathrm{mGal}$ occur over metamorphic rocks. A gravity low of about $5 \mathrm{mGal}$ relief and $10-15 \mathrm{~km}$ wide is centered about $4 \mathrm{~km}$ north of the point where the San Gabriel fault crosses the profile. Unfortunately, the regional gravity coverage is insufficient to determine whether this low parallels the fault or whether it is associated with a local lowdensity pluton. The gravity low does coincide roughly with a zone of relatively low seismic velocities that extends to $5 \mathrm{~km}$ depth just north of the San Gabriel fault (Gary Fuis, USGS, written commun., 1996). Gravity values decrease north of the Punchbowl fault. The San Andreas fault is located approximately $5 \mathrm{~km}$ north of the middle of this gravity gradient and coincides with a small local low within the gradient at $\mathrm{km} 84$. The projection onto the profile of the Llano fault, mapped as a Holocene (?) thrust fault dipping to the south (Ponti and Burke, 1980), occurs near the base of the gradient at approximately $\mathrm{km} 95$.

The lowest values along the profile in the Mojave Desert region $(-30 \mathrm{mGal})$ occur just $15-20 \mathrm{~km}$ north of the San Andreas fault (Fig. 4b). Regional gravity data suggest that this gravity low may be a westward extension of the large gravity low over the Hesperia basin (Fig. 5b). The Mirage Valley fault projects onto the profile at about $\mathrm{km} 121$ where values again begin to increase. The profile crosses obliquely several northwest-trending gravity highs (amplitudes of less than $20 \mathrm{mGal}$ ). Most of the gravity gradients correspond to mapped faults or projections of mapped faults onto the profile. The gravity lows are apparently caused by accumulations of basin fill.

In the Mojave Desert, gravity values along the profile remain below $-15 \mathrm{mGal}$, even over areas where crystalline basement rocks are exposed, suggesting that the crystalline rocks are less dense than those of the San Gabriel Mountains (minimum value along profile - 8 $\mathrm{mGal}$ ) or that the exposed rocks are somehow structurally decoupled from low-density rocks below. Density measurements of rock samples from the Mojave Desert range from 2580 to $2780 \mathrm{~kg} / \mathrm{m}^{3}$, averaging about $2660 \mathrm{~kg} / \mathrm{m}^{3}$ (Ross, 1972; Mabey, 1960). Density measurements on crystalline rocks from the San Gabriel Mountains average $2720 \mathrm{~kg} / \mathrm{m}^{3}$ (Ross, 1972).

\section{Depth to Basement}

Method

An updated version of the method developed by Jachens and Moring (1990) is used here by incorporating drill hole data to model depth to basement (Bruce Chuchel, U.S. 
Geological Survey, written commun., 1996). Input parameters include the residual gravity field, the exposed geology, and the variation of density with increasing depth within the basin deposits. Depths where drill holes penetrate basement rock can also be input into the model and provide useful constraints. The method attempts to separate the gravity field into two components, one caused by variations of density within the preCenozoic basement and the other caused by variations of thickness of the Cenozoic basin fill (Fig. 6). To accomplish this, the gravity data are separated into observations made on basement outcrops and observations made on Cenozoic deposits. The second set of observations is inverted to yield the thickness of Cenozoic deposits, based on an estimate of the density-depth function that characterizes the Cenozoic deposits. The inversion is complicated by two factors: (1) basement gravity stations are influenced by the gravity anomaly caused by low-density deposits in nearby basins, and (2) the basement gravity field varies because of lateral density variations in the basement. The inversion presented here does not take into account lateral variations in the density distribution of the Cenozoic deposits.

To overcome these difficulties, a first approximation of the basement gravity field is determined by interpolating a smooth surface through all gravity values measured on basement outcrops (curve labeled "iteration 1" in upper part of Figure 6B). Basement gravity values are also estimated at locations where drill holes penetrated basement, by subtracting the calculated basin gravity anomaly (using the assumed density-depth function) from the observed gravity value. The basin gravity is then the difference between the observed gravity field on the original map and the first approximation of the basement gravity field. The basin gravity field is used to calculate the first approximation of the thickness of Cenozoic deposits. The thickness is forced to zero where basement rock is exposed. This first approximation of the basement gravity is too low near basins because of proximity of the low-density deposits to the basement stations. The basement gravity station values are "corrected" for the effects of the lowdensity deposits (the effects are calculated directly from the first approximation of the thickness of the Cenozoic deposits) and a second approximation of the basement gravity field is made by interpolating a smooth surface through the corrected basement gravity observations. This leads to an improved estimate of the basin gravity field, an improved depth to basement and a new correction to the basement gravity values. This procedure is repeated until successive iterations produce no significant changes in the basement gravity field. 
Results

The model is based on 2-km grids of the isostatic residual gravity field and of the geology. The geology grid is divided into three basic units: (1) Cenozoic sedimentary rocks and deposits, (2) Cenozoic volcanic rocks, and (3) pre-Cenozoic sedimentary, metamorphic and igneous basement rocks (Fig. 2). Tertiary intrusive rocks are also considered "basement" for this study. The density contrasts listed in Table 1 are based on a reference density of $2670 \mathrm{~kg} / \mathrm{m}^{3}$.

Drill hole data used to provide control on the depth to basement modeling are from Smith (1964), Durham and Yerkes (1964), Yerkes and Showalter (1990), Schoellhamer and others (1981) and Yerkes (1972). Porosity data from 4000 core samples from the Los Angeles and Ventura basins provided information for the density-depth curve used to model the sedimentary section in the Los Angeles basin (Table 1; McCulloh, 1967). We used the average porosity curve (McCulloh, 1967, his Fig. 4) to calculate the densities of the sedimentary sequence assuming that the pore spaces of the rocks are filled with water. The densities calculated from McCulloh's data tend to be slightly lower (50 to 140 $\mathrm{kg} / \mathrm{m}^{3}$ ) than the densities measured in two borehole gravity surveys in the Long Beach area (Beyer and others, 1985). Although the borehole data provide very accurate data on the densities of the sedimentary sequence, it only samples the rocks beneath Long Beach and may not be appropriate for other areas of the basin. For this reason, we show the results based on McCulloh's porosity data, which presumably reflect the average densities of the sedimentary sequence for the entire Los Angeles basin. Nonetheless, the difference in the results between using the borehole gravity density-depth function and using McCulloh's porosity data is minor (less than $8 \mathrm{mGal}$ difference in the basement gravity field and $1 \mathrm{~km}$ difference in the modeled thickness of fill).

Mabey (1960) provided density information for the sedimentary sequence of the Mojave Desert. The density-depth function for the volcanic sequence is based on density measurements and logs of Cenozoic volcanic rocks in northern California (Smith, 1992); according to Smith (1992), the densities of volcanic rocks do not differ greatly from those of other Tertiary rocks. The density-depth functions used in the model do not account for lateral density variations within the Cenozoic units.

Table 1. Density-depth function used in the model.

\begin{tabular}{cccc}
$\begin{array}{c}\text { Depth interval } \\
(\mathrm{m})\end{array}$ & $\frac{\text { Density contrast }\left(\mathrm{kg} / \mathrm{m}^{3}\right)}{\text { sedimentary }}$ & $\frac{\text { Density contrast }\left(\mathrm{kg} / \mathrm{m}^{3}\right)}{\text { sedimentary }(\mathrm{Mojav})}$ & $\frac{\text { Density contrast }\left(\mathrm{kg} / \mathrm{m}^{3}\right)}{\text { volcanic }}$ \\
\hline $0-500$ & -600 & -500 & -450 \\
$500-1000$ & -550 & -450 & -400 \\
$1000-1500$ & -400 & -350 & -350 \\
$>1500$ & -250 & -250 & -250 \\
& & &
\end{tabular}


The modeled configuration of the Los Angeles basin (Fig. 7) is somewhat similar to that of McCulloh (1960). The model does not exactly match the well depths at all locations because of interpolation and the coarse $2-\mathrm{km}$ spacing. The average misfit between the modeled depth to basement and the actual well depth to basement for 143 wells is $165 \mathrm{~m}$.

The model indicates a nearly rectangular basin beneath Los Angeles (Fig. 7). The southwestern margin of the deep part of the basin approximately follows the NewportInglewood fault zone. The linear northeastern boundary coincides with the Whittier fault. North of the Whittier fault, the basement rocks beneath the San Gabriel Valley are buried as deep as $3 \mathrm{~km}$. A northwest-trending basement ridge bisects the eastern part of the basin and coincides with the Anaheim nose. A local, north-northeast-trending basin east of the San Jose Hills has more than $1 \mathrm{~km}$ of fill.

The basement gravity field (Fig. 8) indicates large positive anomalies over the southeast end of the Palos Verdes Hills, the eastern Santa Monica Mountains, the western Transverse ranges, the southern Sierra Nevada Mountains, and the western Peninsular Range. Basement gravity lows occur over the Chatsworth Hills, the San Bernardino Mountains, and the Mojave Desert. The Mojave Desert and San Bernardino Mountains are characterized by low basement gravity values (as low as -25 to $-30 \mathrm{mGal}$ ) whereas the San Gabriel Mountains and western Peninsular Ranges show basement gravity values close to $0 \mathrm{mGal}$ or higher. The transition between the basement gravity highs in the San Gabriel Mountains and the basement gravity lows of the Mojave Desert occurs along the San Andreas fault, but shifts to the San Jacinto fault to the southeast (Fig. 8). South of the Transverse Ranges within the study area, the San Jacinto fault, not the San Andreas, marks a fundamental change in basement gravity values.

\section{Discussion}

The modeled results will greatly improve using a more accurate density-depth function that takes into account lateral density variations in the Cenozoic sequence. Basement gravity highs over the San Joaquin Hills and the Whittier hills (Fig. 8) are exaggerated because a more likely density contrast for the Miocene rocks exposed there is about -200 to $-400 \mathrm{~kg} / \mathrm{m}^{3}$, much smaller than the density contrast assumed in the model for the upper $500 \mathrm{~m}\left(-600 \mathrm{~kg} / \mathrm{m}^{3}\right.$; Table 1). For example, wells indicate that $1-2 \mathrm{~km}$ of Cenozoic deposits covers the San Joaquin Hills. For that given thickness of fill, a smaller density contrast will produce a smaller basin gravity anomaly. A smaller basement gravity high would then be necessary to offset the negative basin gravity anomaly to match the 
observed gravity values. However, the gravity high over the San Joaquin Hills also coincides with an aeromagnetic anomaly of nearly $250 \mathrm{nT}$ (U.S. Geological Survey, 1990), suggesting a dense, magnetic mafic source within the basement. Both the basement gravity high and the aeromagnetic high extend to the northwest, possibly as far as the middle of the Los Angeles basin. The source of these gravity and aeromagnetic anomalies could be a Tertiary mafic intrusion (Wright, 1990) or mafic igneous rocks of the western Peninsular Ranges (Langenheim and Jachens, 1993). Miocene diabase dikes exposed locally in the San Joaquin Hills (Vedder and others, 1957) may delineate an underlying mafic intrusion of similar age. However, magnetic susceptibility measurements on the dikes indicate that these rocks are weakly to moderately magnetic $\left(0.0\right.$ to $7.5 \times 10^{-3} \mathrm{SI}$ ), too small to account for the large-amplitude aeromagnetic anomaly. Langenheim and Jachens (1993) suggest that a more likely source of the aeromagnetic anomaly is crystalline rocks of the western Peninsular Ranges. Their interpretation is based on modeling of the aeromagnetic anomaly indicating that the source has a similar geometry and magnetic susceptibility to modeled sources of the western Peninsular Ranges aeromagnetic anomalies.

The basement gravity lows that flank the San Joaquin Hills gravity high to the east and southeast (Fig. 8) probably reflect the presence of lower-density Cretaceous sedimentary rocks that have been included in the "basement" definition according to our model. These rocks are exposed in the Santa Ana Mountains and occur in the Capistrano syncline. If these rocks were not defined as basement, the basement gravity field would be higher in these areas and reflect more accurately the densities of the crystalline basement rocks. The basement gravity low over the Chatsworth Hills is also most likely the result of having defined Cretaceous sedimentary rocks as basement. However, the source of the basement gravity low over the San Jose Hills is enigmatic. Sparse density measurements of the granitic rocks exposed in the San Jose Hills indicate an average density of $2680 \mathrm{~kg} / \mathrm{m}^{3}$, a typical density for granitic rocks. Perhaps the granitic exposures of the San Jose Hills are underthrust by lower-density sedimentary and volcanic rocks. The focal mechanism of the 1988 Upland earthquake is consistent with this inference, indicating a thrust fault dipping $40^{\circ}$ to $50^{\circ}$ north beneath the San Jose Hills (Hauksson and Jones, 1991). Basement gravity lows ( $<0 \mathrm{mGal})$ north and east of San Fernando Valley may also reflect lower-density sedimentary deposits that have been thrust under exposed, denser basement rocks.

Thrusting may also explain the low basement gravity values beneath the Santa Monica Mountains, although the low values also occur over the footwall south of the Santa Monica fault (Fig. 8). Perhaps the transition from this basement gravity low to basement 
gravity high south of the Santa Monica fault, which is controlled by numerous wells along the Newport-Inglewood fault zone, indicates the northernmost extent of mafic basement rocks beneath the basin. Alternatively, it may reflect mafic volcanic and intrusive rocks within the Tertiary fill that are not accounted for in the density-depth function used. Basement gravity values also vary along the Santa Monica fault, from low values to the west to higher values to the east. This transition occurs approximately in the area where the Newport-Inglewood fault zone and Las Cienegas fault intersect the Santa Monica fault. It also occurs where the exposed basement lithology in the Santa Monica Mountains changes from predominantly slate (to the west) to predominantly granite (to the east) and where subsurface basement lithologies in the footwall change from Catalina Schist to metaigneous rocks (Wright, 1990). Further investigations of the densities of the basement rocks accompanied by modeling may lead to a viable source responsible for the basement gravity variations.

An improved density-depth function would provide better thickness estimates; for example, according to our model, the San Fernando basin is $3 \mathrm{~km}$ thick at its northern apex (Fig. 7). However, a well in that vicinity indicates nearly $4 \mathrm{~km}$ of Pliocene gravels; density measurements of the gravels (Corbato, 1963) indicate a substantially lower density contrast than assumed in the model. A lower density contrast would require more basin fill to produce the equivalent basin gravity anomaly.

Another complication in interpreting these results is whether the isostatic residual anomaly reflects solely the density variations in the upper and middle crust. If the topography of the Transverse Ranges is not compensated by an "Airy" root, as assumed in the transformation from complete Bouguer to isostatic residual anomaly, the marked change in basement gravity between the San Gabriel Mountains and the Mojave Desert may not be caused by crustal rocks. However, the steepness of the Complete Bouguer gravity gradient between the San Gabriel Mountains and Mojave Desert (Fig. 4a) suggests crustal sources. Furthermore, density and velocity measurements indicate that at least part of the apparent change in basement gravity could be caused by upper crustal rocks. McCaffree Pellerin and others (1995) found that the Mendenhall gneiss and the San Gabriel anorthosite complex have seismic velocities of 6.5 and $6.4 \mathrm{~km} / \mathrm{s}$, significantly higher than the average velocity of Mojave granitic rocks of $5.7 \mathrm{~km} / \mathrm{s}$. This difference in seismic velocities would give rise to a density contrast of at least $100 \mathrm{~kg} / \mathrm{m}^{3}$ between the crystalline rocks of the San Gabriel Mountains and the granitic rocks of the Mojave Desert, more than sufficient to account for the 25-30 mGal change in basement gravity if the density contrast extends to $10 \mathrm{~km}$. A density contrast of $700 \mathrm{~kg} / \mathrm{m}^{3}$ would be necessary to produce a $30 \mathrm{mGal}$ anomaly if the source is restricted to the upper $10 \mathrm{~km}$. 
If indeed the source of the gravity anomaly lies in the upper crust, then the density contrast inferred from the gravity data would predict a seismic velocity increase of 0.2 $\mathrm{km} / \mathrm{s}$ for the upper $10 \mathrm{~km}$ (Christensen and Mooney, 1995) across the San Andreas fault. However, modeling of the complete Bouguer gravity anomaly data in conjunction with seismic constraints can further constrain the source of these anomalies and help resolve the deep crustal structure of the Mojave Desert-San Gabriel Mountains region.

\section{Conclusion}

Detailed gravity data collected along the LARSE transect confirm and add detail to previously mapped large gravity anomalies over the Los Angeles basin, the Mojave Desert and the San Gabriel Mountains. In order to isolate the sources of these anomalies, the observed isostatic gravity anomalies were separated into basin and basement components using an iterative technique by Jachens and Moring (1990). The results of the model will be greatly improved with (1) more well or geophysical information on the depth to basement and (2) density-depth functions that incorporate lateral density variations in the Cenozoic fill. However, the model does indicate that the large isostatic gravity low over the Los Angeles basin is caused by the accumulation of more than 10 $\mathrm{km}$ of Cenozoic sedimentary and volcanic deposits. The basement gravity fieid indicates that the LARSE transect crosses the northern extension of a pronounced basement gravity and aeromagnetic high over the San Joaquin Hills, reflecting basement rocks of the western Peninsular Ranges or, alternatively, Miocene basic intrusive rocks. The basement gravity field indicates that a major decrease in the density of basement rocks from the San Gabriel Mountains to the Mojave Desert occurs approximately at the San Andreas fault. However, whether this prominent change in basement gravity truly reflects (1) change in densities in the upper and middle crust or (2) reflects deeper density variations can be further addressed by modeling the complete Bouguer gravity anomaly using constraints from seismic data. The steepness of the gravity gradient together with velocity and density measurements of exposed crystalline rocks are consistent with the first scenario.

\section{References}

Beyer, L.A., Robbins, S.L., and Clutsom, F.G., 1985, Basic data and preliminary density and porosity profiles for twelve borehole gravity surveys made in the Los Angeles, San Joaquin, Santa Maria, and Ventura basins, California: U.S. Geological Survey Open-File Report 85-42, 66 p. 
Bohannon, R.G, 1975, Mid-Tertiary conglomerates and their bearing on Transverse Range tectonics, southern California, in Crowell, J.C., ed., San Andreas fault in southern California: California Division of Mines and Geology Special Report 118, p. 75-82.

Bortugno, E.J., and Spittler, T.E., 1986, Geologic map of the San Bernardino quadrangle: California Division of Mines and Geology, Regional Geologic Map Series Map 3A1, scale 1:250,000.

Christenson, N.I., and Mooney, W.D., 1995, Seismic velocity structure and composition of the continental crust: A global view: Journal of Geophysical Research, v. 100, no. B7, p.9761-88.

Corbato, C.E., 1963, Bouguer gravity anomalies in the San Fernando Valley: University of California Publications in Geological Sciences, v. 46, no. 1, p. 1-32.

Crook, R. Jr., Allen, C.R., Kamb, Barclay, Payne, C.M., and Proctor, R.J., 1987, Quaternary geology and seismic hazard of the Sierra Madre and associated faults, western San Gabriel Mountains in Recent Reverse Faulting in the Transverse Ranges, California: U.S. Geological Survey Professional Paper 1339, p. 27-63.

Crouch, J.K., and Suppe, John, 1993, Late Cenozoic tectonic evolution of the Los Angeles basin and inner California borderland: A model for core complex-like crustal extension: Geological Society of America Bulletin 105, no. 11, p. 14151434.

Crowell, J.C., 1976, Implications of crustal stretching and shortening of coastal Ventura basin, California in D.G. Howell, ed., Aspects of the geologic history of the California continental borderland: Pacific Section, AAPG, Misc. Publ. 24, p. 365382.

Dibblee, T.W., Jr., 1981, Regional structure of the Mojave Desert: U.S. Geological Survey Open-File Report 81-503, p. 26-28.

Durham, D.L., and Yerkes, R.F., 1964, Geology and oil resources of the eastern Puente Hills, southern California: U.S. Geological Survey Professional Paper 420-B, 62 p.

Hauksson, E., and Jones, L.M., 1991, The 1988 and 1990 Upland earthquakes: left-lateral faulting adjacent to the central Transverse Ranges: Journal of Geophysical Research, v. 96, no, B5, p. 8143-8165.

International Union of Geodesy and Geophysics, 1971, Geodetic Reference System 1967: International Association of Geodesy Special Publication no. 3, 116 p.

Jachens, R.C., and Griscom, Andrew, 1985, An isostatic residual gravity map of California-A residual map for interpretation of anomalies from intracrustal sources in Hinze, W.J., ed., The Utility of Regional Gravity and Magnetic Maps: Society of Exploration Geophysicists, Tulsa, Oklahoma, p. 347-360.

Jachens, R.C., and Moring, B.C., 1990, Maps of the thickness of Cenozoic deposits and the isostatic residual gravity over basement for Nevada: U.S. Geological Survey Open-File Report 90-404, 15 p., 2 plates.

Jennings, C.W., 1994, Fault activity map of California and adjacent areas: California Division of Mines and Geology California Geologic Data Map 6, scale 1:750,000.

Jennings, C.W., 1962, Geologic map of California-Long Beach: California Division of Mines and Geology Map, scale 1:250,000.

Langenheim, V.E., and Jachens, R.C., 1993, Nature of basement rocks under the Los Angeles basin, southern California, as inferred from aeromagnetic data: GSA Abstracts with Programs, v. 25, p. 66.

Luyendyk, B.P., and Hornafius, J.S., 1987, Neogene crustal rotations, fault slip, and basin development in southern California, in R.V. Ingersoll and W.G. Ernst, Eds., 
Cenozoic basin development of coastal California: Englewood Cliffs, New Jersey, Prentice-Hall, Inc., Rubey v. VI, p. 259-283.

McCaffree Pellerin, C.L., Christensen, N.I., and Fuis, G., 1995, Seismic properties of rocks from the Mojave-San Gabriel region in southern California: American Geophysical Union Transactions, v. 76, no. 46, p. 348.

McCulloh, T.H., 1960, Gravity variations and the geology of the Los Angeles basin of California: U.S. Geological Survey Professional Paper 400-B, p. 320-325.

McCulloh, T.H., 1967, Mass properties of sedimentary rocks and gravimetric effects of petroleum and natural-gas reservoirs: U.S. Geological Survey Professional Paper $528-\mathrm{A}, 50 \mathrm{p}$.

Morelli, C.(Ed.), 1974, The International Gravity Standardization Net, 1971: International Association of Geodesy Special Publication no. 4, 194 p.

Oliver, H.W., Chapman, R.H., Biehler, S.H., Robbins, S.L., Hanna, W.F., Griscom, Andrew, Beyer, L.A., and Silver, E.A., 1981, Gravity map of California and its continental margin: California Division of Mines and Geology, Geologic Data Map No. 3, scale 1:750,000.

Ponti, D.J., and Burke, D.B., Map showing Quaternary geology of the eastern Antelope Valley and vicinity, California: U.S. Geological Survey Open-File Report 80-1064, scale $1: 62,500$.

Roberts, C.W., and Jachens, R.C., 1986, High-precision gravity stations for monitoring vertical crustal motion in southern California: U.S. Geological Survey Open-File Report 86-44, 76 p.

Ross, D.C., 1972, Petrographic and chemical reconnaissance study of some granitic and gneissic rocks near the San Andreas fault from Bodega Head to Cajon Pass, California: U.S. Geological Survey Professional Paper 698, 92 p., 2 plates, scale $1: 250,000$.

Schoellhamer, J.E., Woodford, A.O., Vedder, J.G., Yerkes, R.F., and Kinney, D.M., 1981, Geology of the northern Santa Ana Mountains, California: U.S. Geological Survey Professional Paper 420-D, 109 p.

Sheffels, B., and McNutt, M., 1986, Role of subsurface loads and regional compression in the isostatic balance of the Transverse Ranges, California: Evidence for intracontinental subduction: Journal of Geophysical Research, v. 91, p. 6419-6431.

Smith, M.B., 1964, Map showing distribution and configuration of basement rocks in California (North Half)(South Half): U.S. Geological Survey Oil and Gas Investigations Map OM-215, scale 1:500,000.

Smith, Neal, 1992, Gravity interpretation of San Pablo Bay and vicinity, in Wright, T.L., ed., Field trip guide to Late Cenozoic geology in the north bay region: Northern California Geological Society Guidebook, p. 71-80.

U.S. Geological Survey, 1990, Aeromagnetic map of parts of the San Diego, Santa Ana, and adjacent $1^{\circ}$ by $2^{\circ}$ quadrangles, California: U.S. Geological Survey Open-File Report 90-206, scale 1:250,000.

Vedder, J.G., Yerkes, R.F., and Schoelhamer, J.E., 1957, Geologic map of the San Joaquin Hills-San Juan Capistrano area, Orange County, California: U.S. Geological Survey Oil and Gas Investigations Map OM-193, scale 1:24,000.

Wright, T.L., 1990, Structural geology and tectonic evolution of the Los Angeles basin, California in Biddle, K.T., ed., Active Tectonic Basins: AAPG Memoir 52, p. 35134.

Yerkes, R.F., 1972, Geology and oil resources of the western Puente Hills area, southern California: U.S. Geological Survey Professional Paper 420-C, 63 p. 
Yerkes, R.F., and Showalter, P.K., 1990, Exploratory wells drilled in the Los Angeles 1:100,000 quadrangle, California: U.S. Geological Survey Open-File Report 90-627, 47 p., 1 plate. 


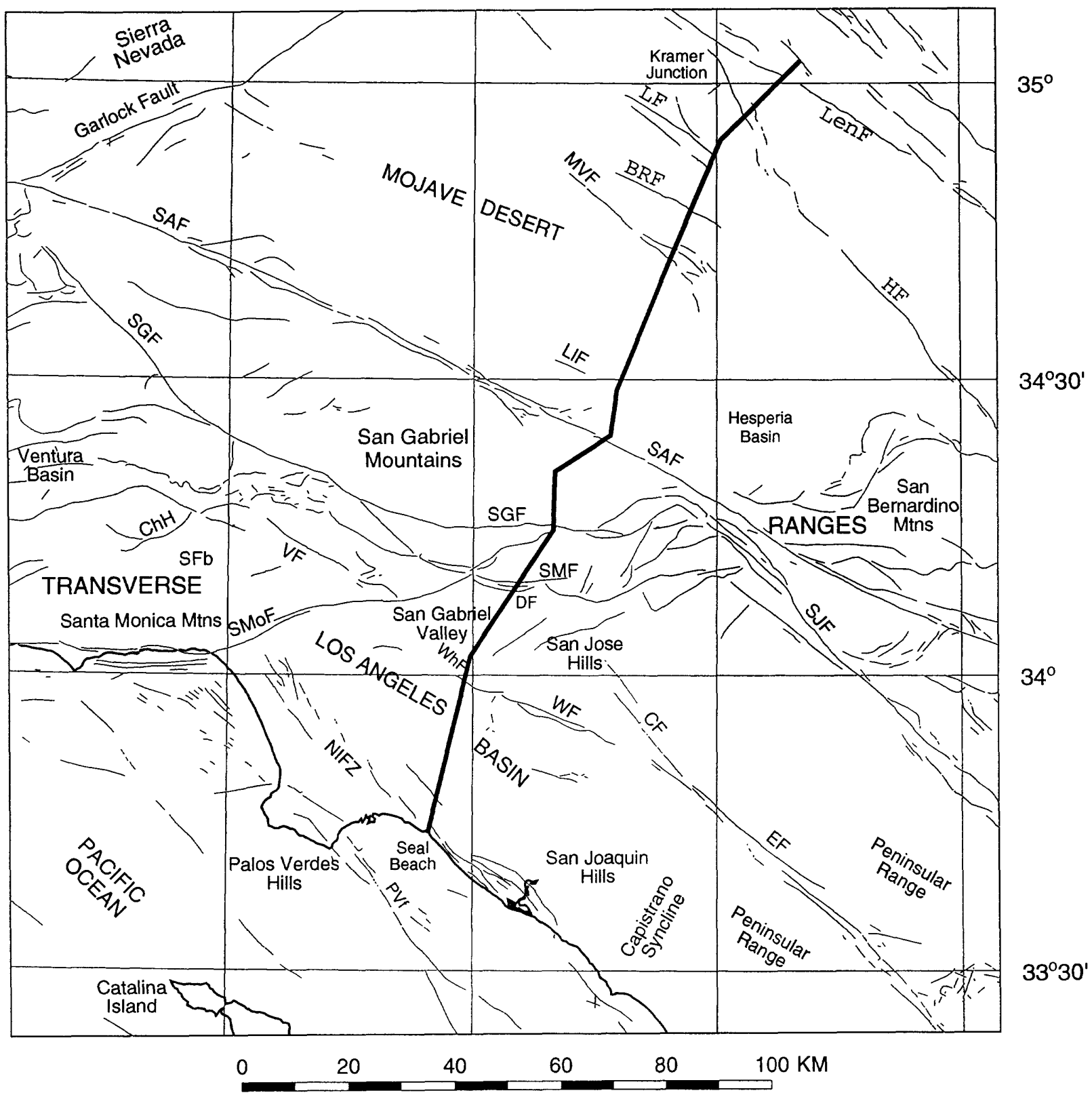

Figure 1. Index map. Heavy dark line shows location of the LARSE Line 1 transect. BRF, Blake Ranch fault; CF, Chino fault; ChH, Chatsworth Hills; EF, Elsinore fault; HF, Helendale fault; LF, Leuman fault; LenF, Lenwood fault; LIF, Llano fault; MVF, Mirage Valley fault; NIFZ, Newport-Inglewood fault zone; PVf, Palos Verdes fault; SAF, San Andreas fault; SFb, San Fernando basin; SGF, San Gabriel fault; SJF, San Jacinto fault; SMF, Sierra Madre fault; SMoF, Santa Monica fault; VF, Verdugo fault; WF, Whittier fault; WhF, Whittier Heights fault. Fault locations from Jennings (1994). 


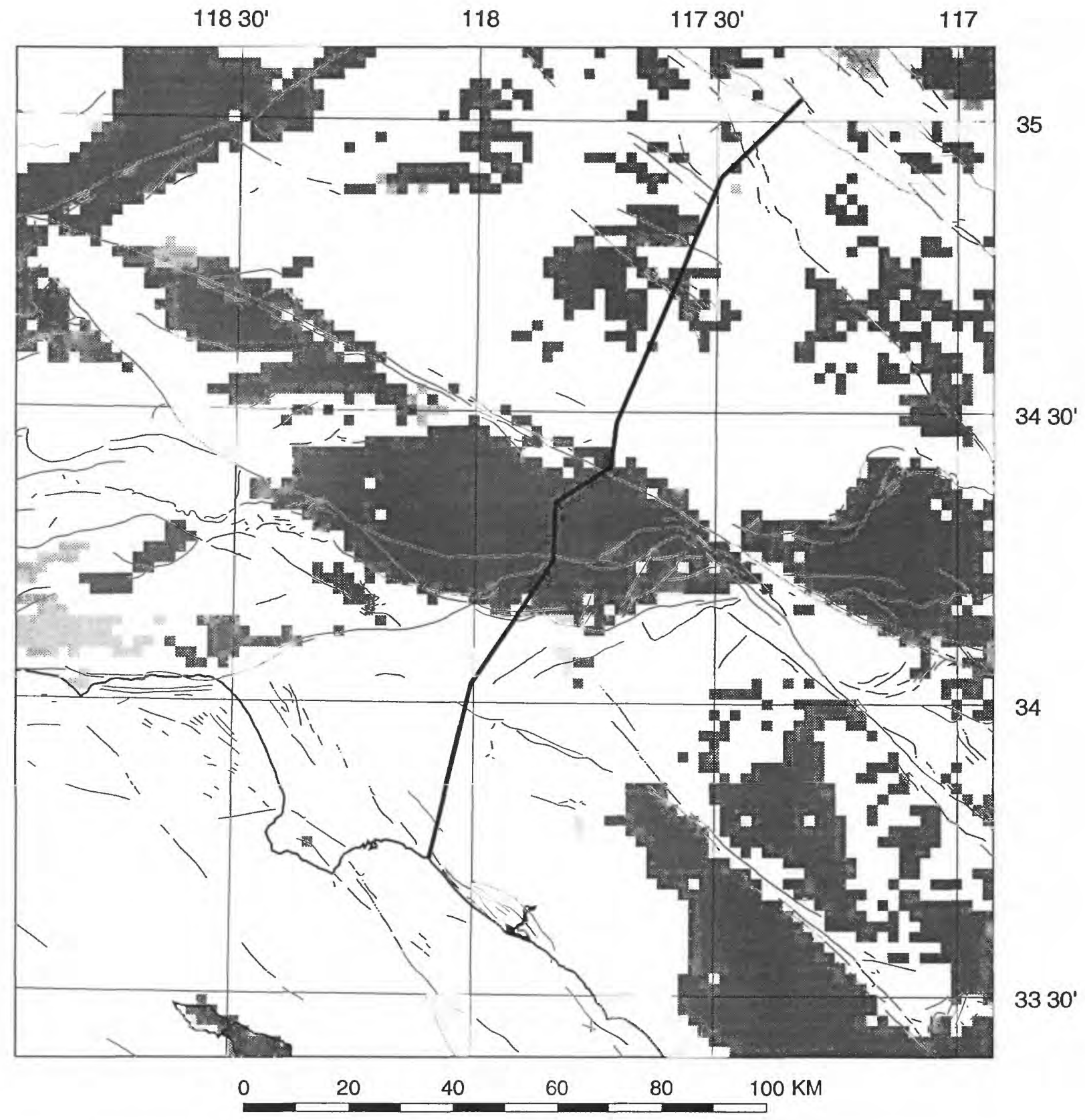

Figure 2. Geologic grid of area (input into iterative model). Heavy dark line shows location of the LARSE Line 1 transect. Dark areas denote pre-Cenozoic outcrops; lightly shaded regions, Cenozoic volcanic rocks. White areas, Cenozoic sedimentary rocks. See Figure 1 for reference. 


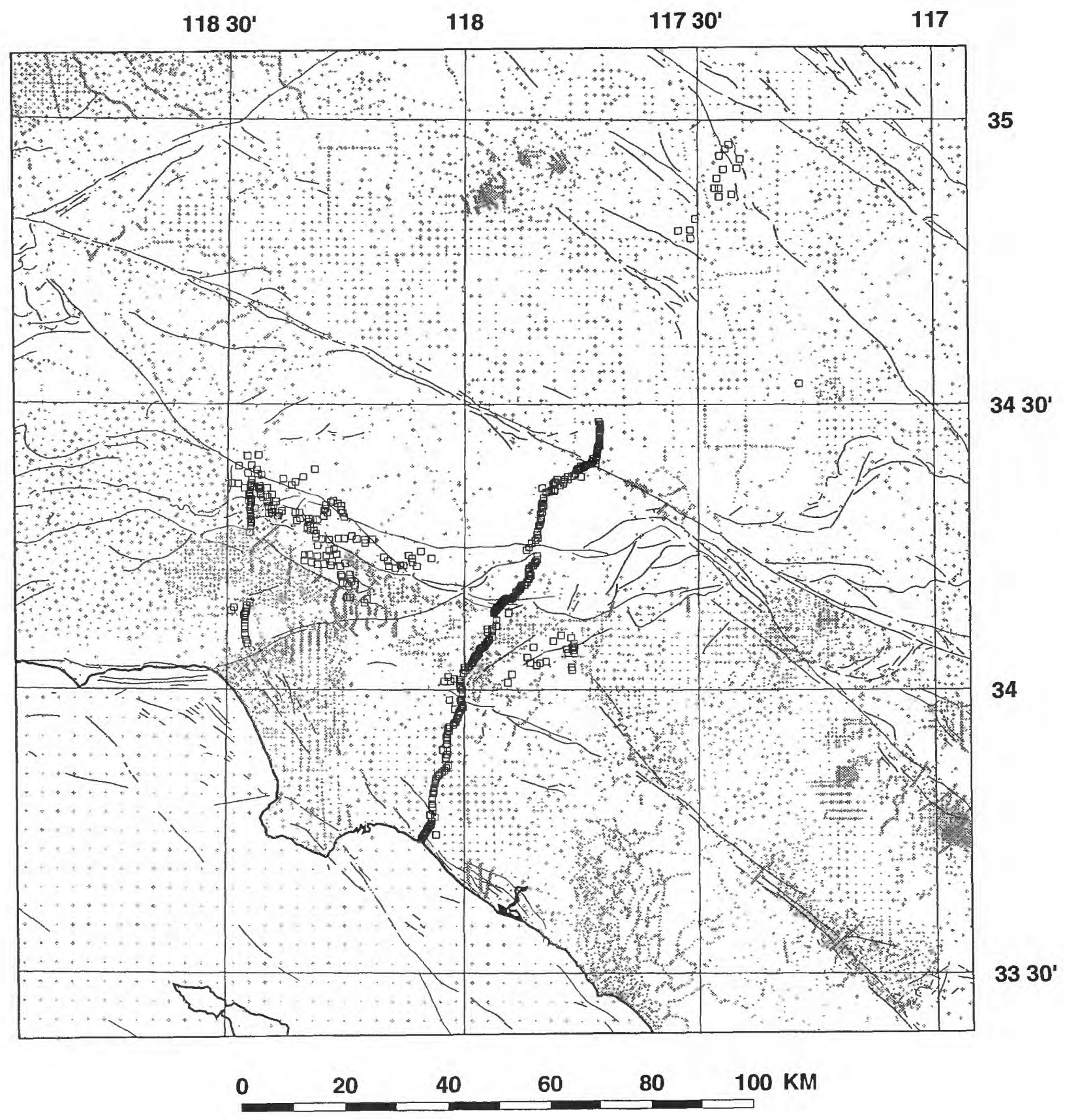

Figure 3. Map of gravity station coverage. Gray crosses, previously collected gravity stations; black boxes, new stations. See Figure 1 for reference. 
BOUGUER GRAVITY, IN MILLIGALS

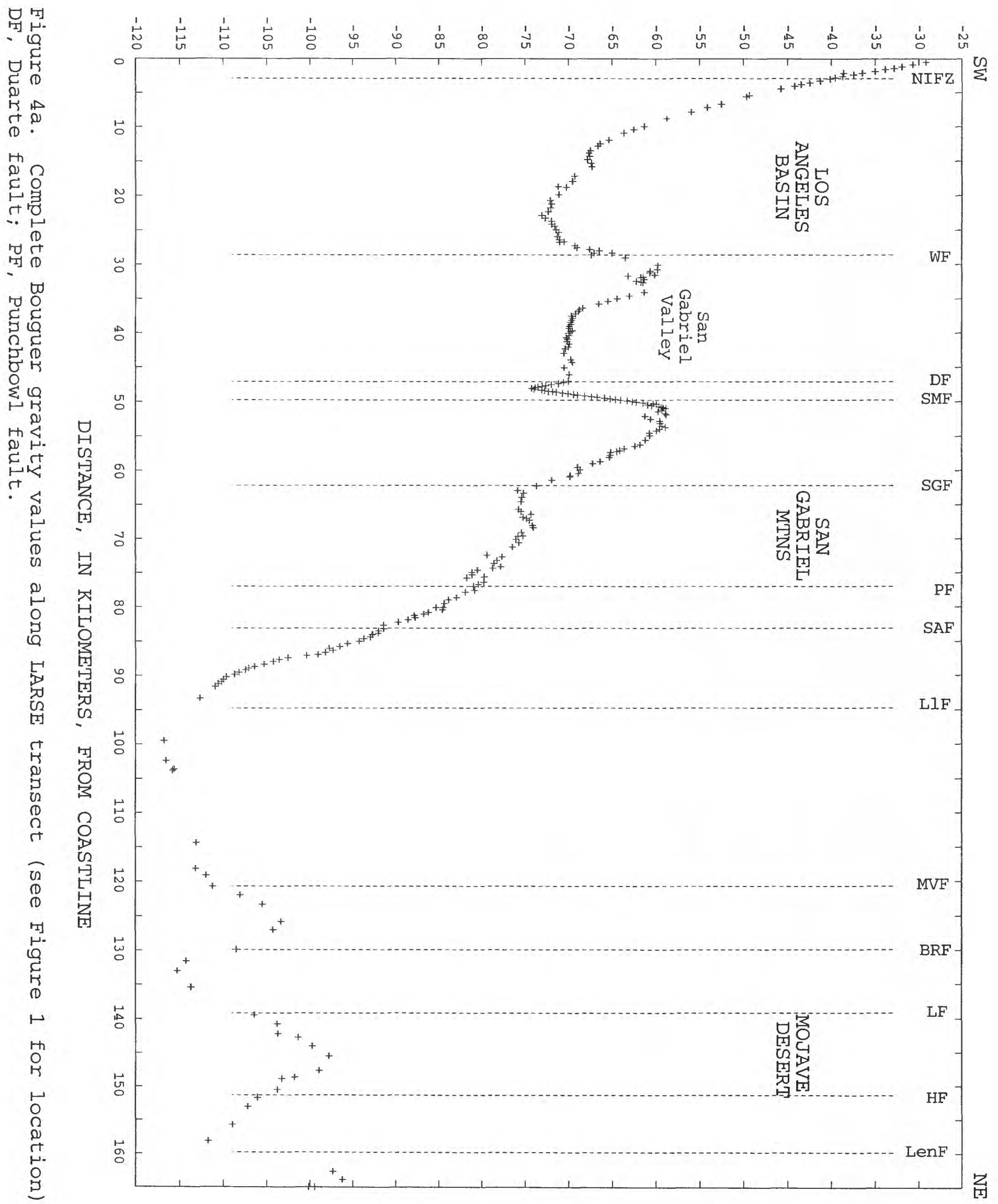


ISOSTATIC GRAVITY, IN MILLIGALS

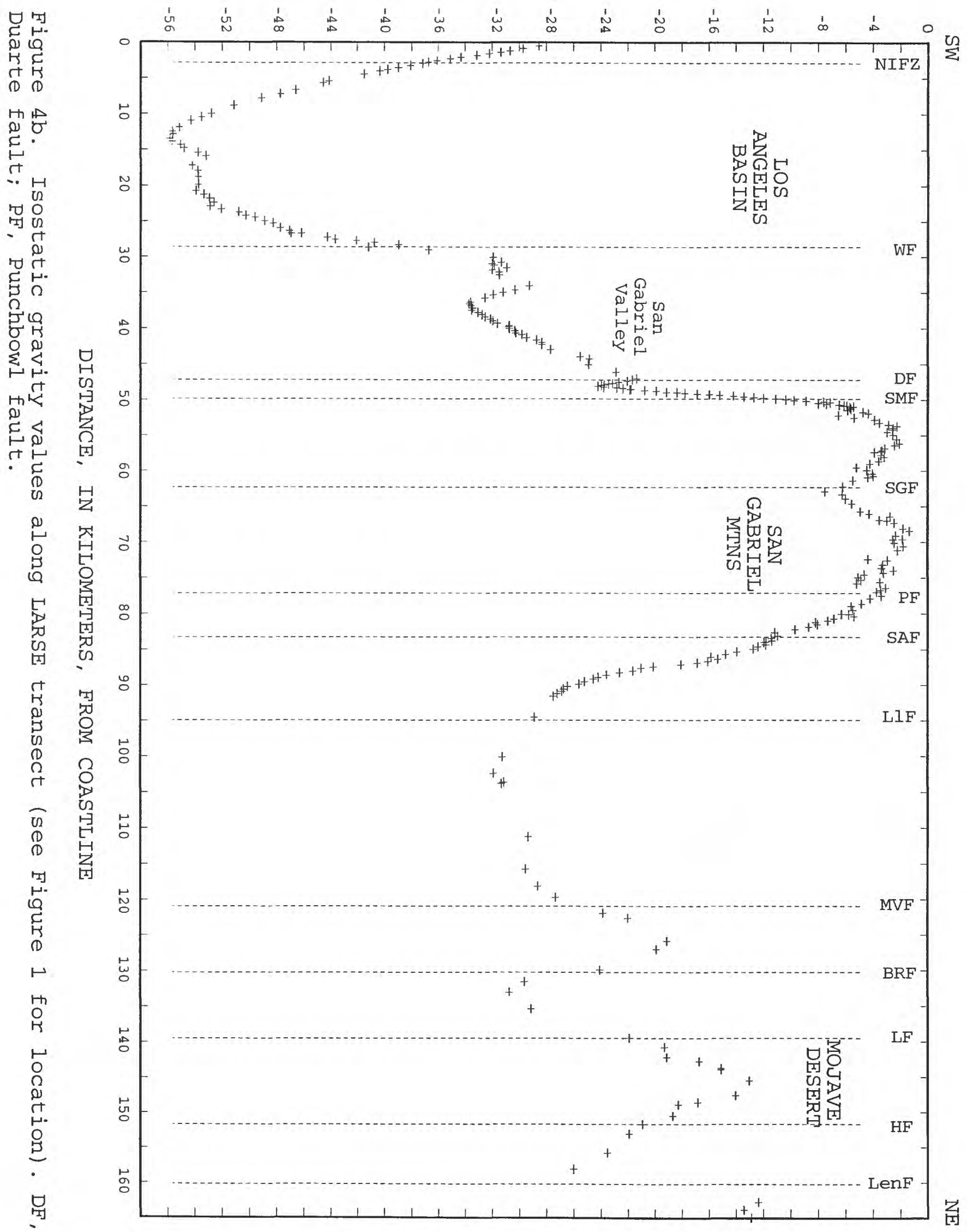




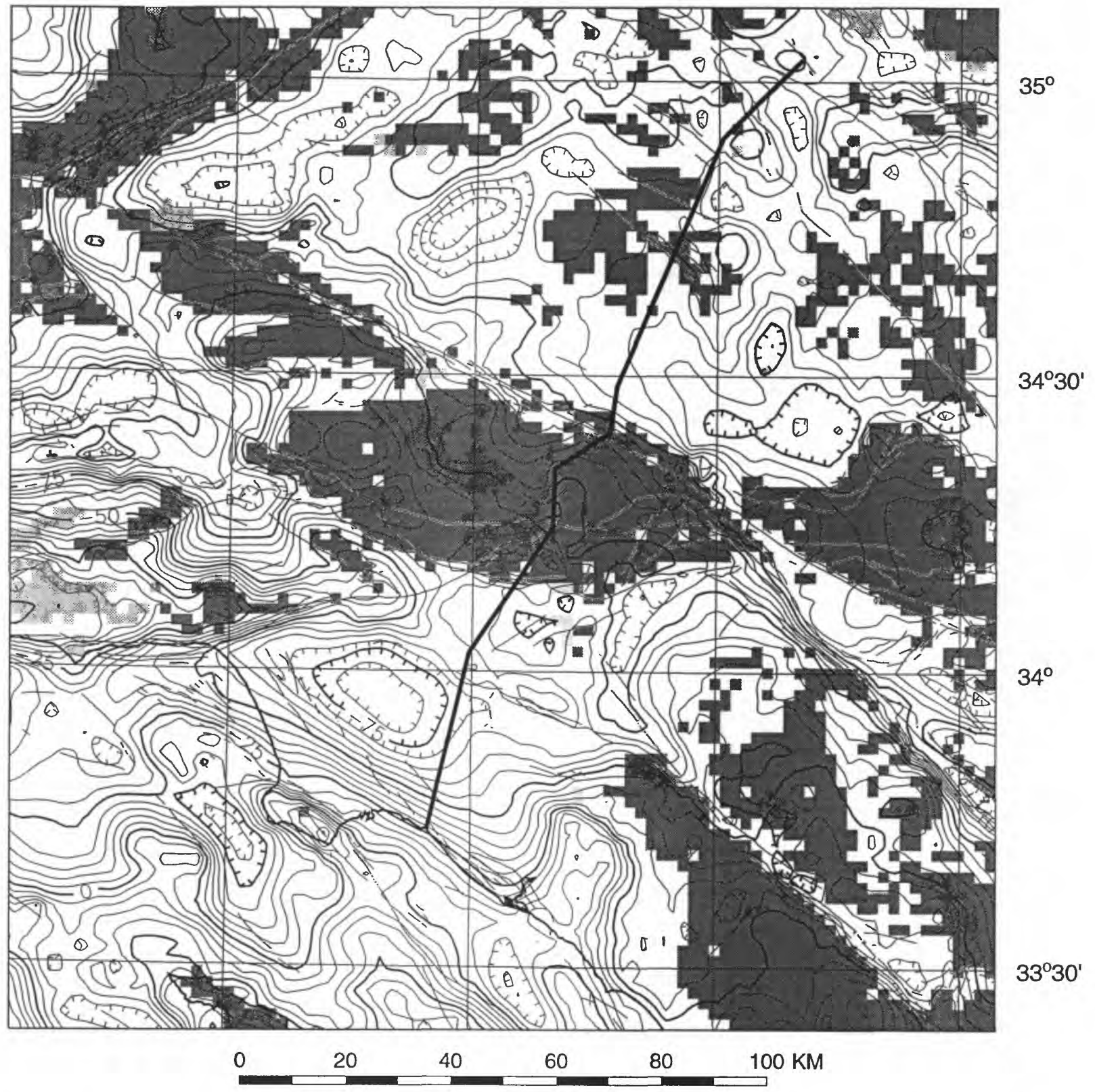

Figure 5a. Complete Bouguer gravity map. Contour interval, 5 mGal. See Figure 1 for reference. 


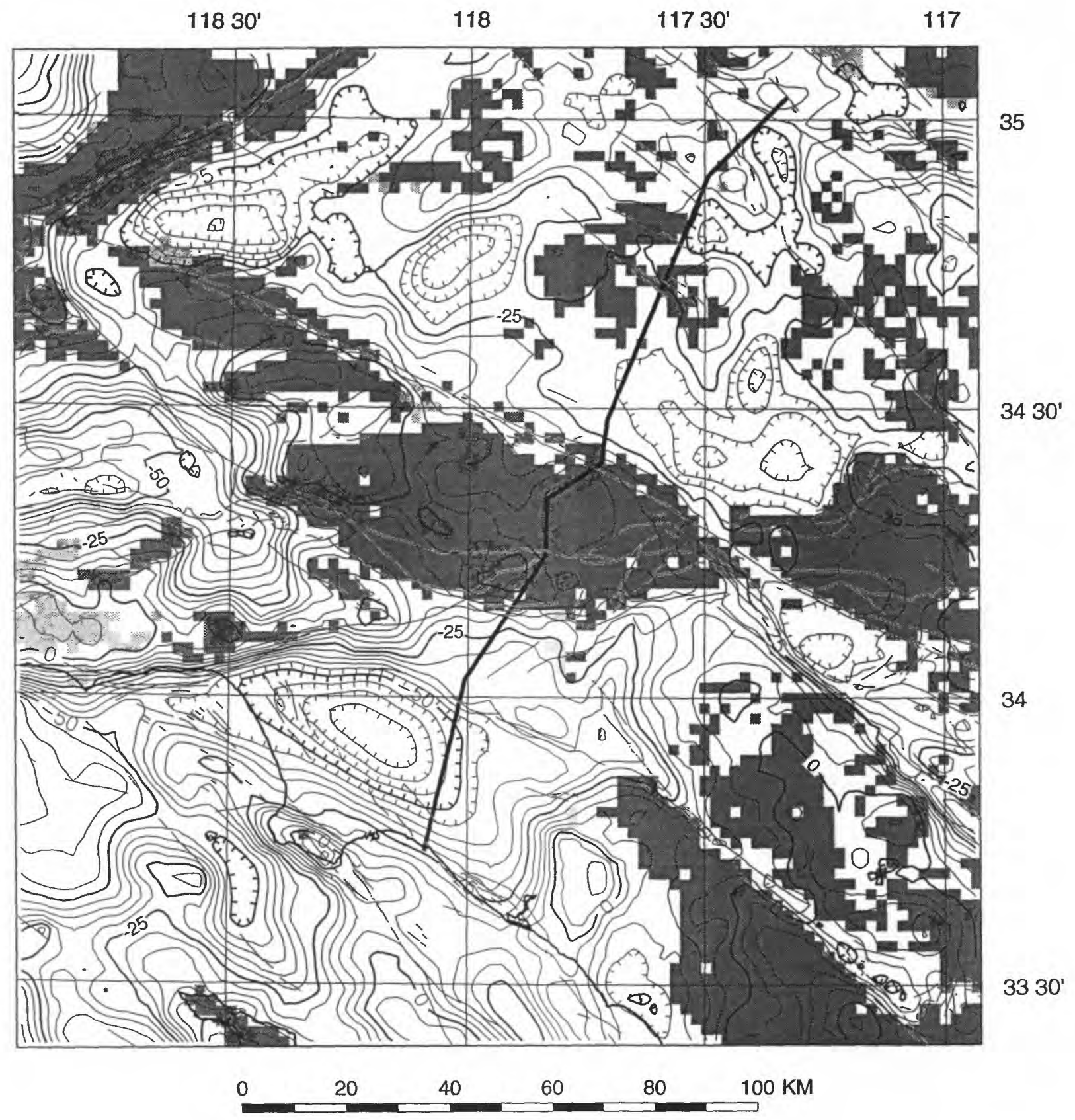

Figure 5b. Isostatic gravity map. Contour interval 5 mGal. See Figure 1 for explanation. 

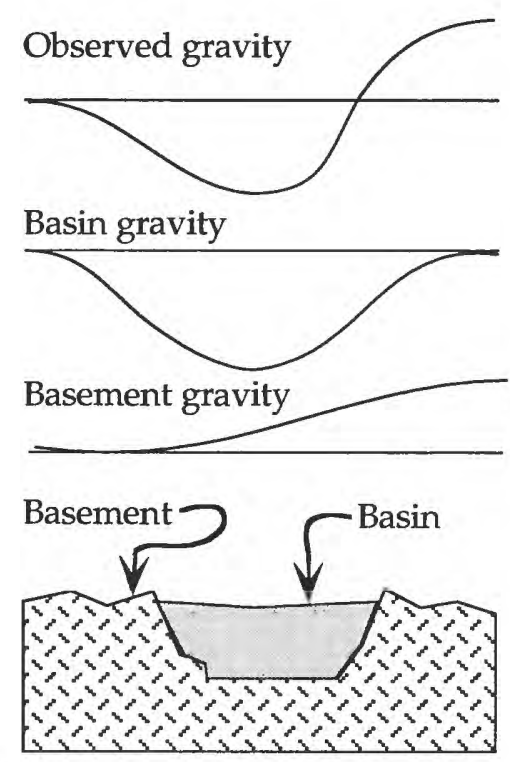

A
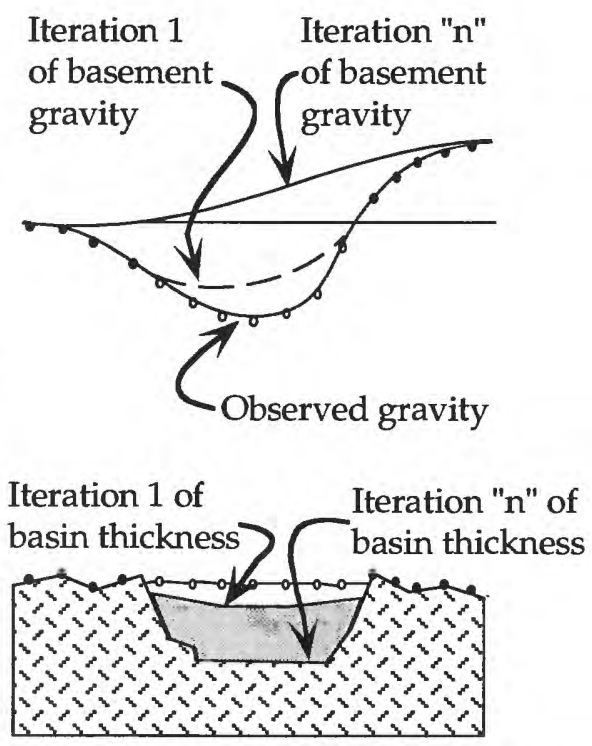

B

Figure 6. Schematic representation of the gravity separation procedure. "n" represents final iteration of basin-fitting procedure. From Jachens and Moring (1990). 


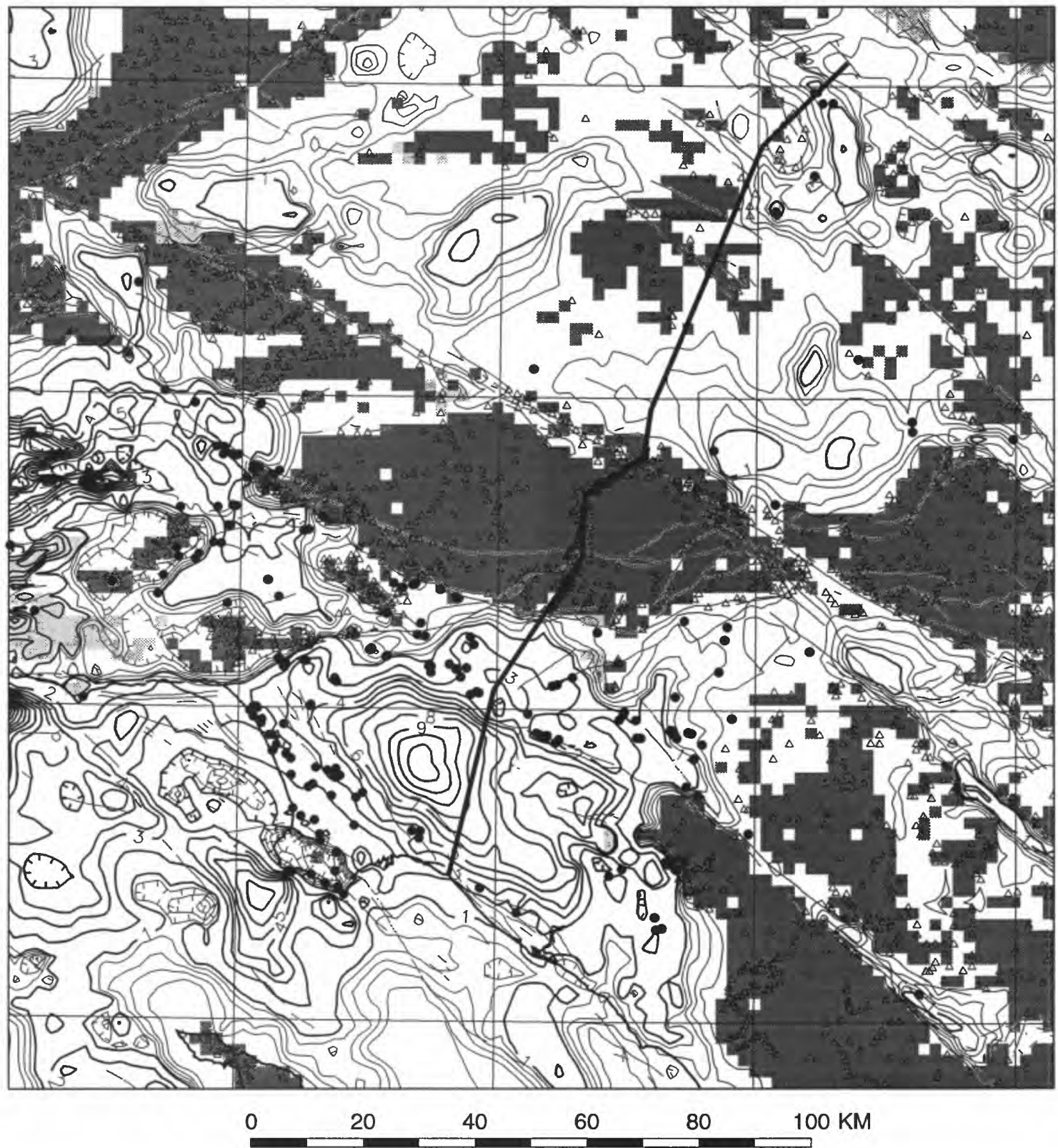

Figure 7. Thickness of Cenozoic deposits. Contour interval, $200 \mathrm{~m}, 1 \mathrm{~km}$. Heavy line marks location of LARSE transect. Triangles, gravity stations measured on basement; black circle, well that penetrated basement rocks. Note: hachured contours reflect basement highs. 


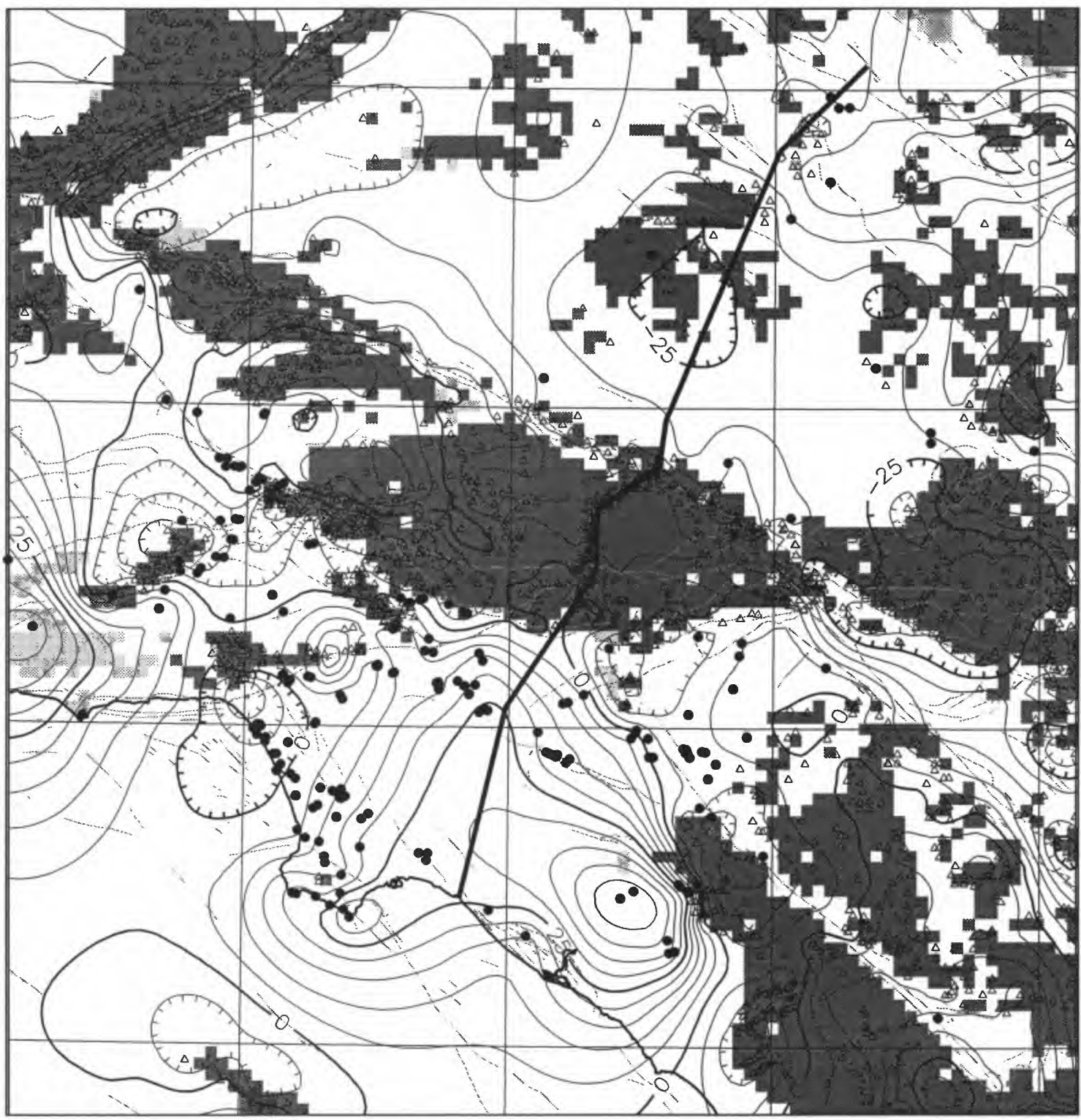

Figure 8. Basement gravity field. Contour interval, $5 \mathrm{mGal}$. Heavy line marks location of the LARSE transect. Triangles, gravity stations measured on basement. Black circles, wells that penetrated basement rocks. See Figure 1 for reference. 